Summer 2014

\title{
Regulating Water and War in Iraq: A Dangerous Dark Side of New Governance
}

Tracey Leigh Dowdeswell

Osgoode Hall Law School, York University

Patricia Hania

University of Saskatchewan, patricia.hania@usak.ca

Follow this and additional works at: https://www.repository.law.indiana.edu/ijgls

Part of the Environmental Law Commons, International Law Commons, Military, War, and Peace Commons, and the Water Law Commons

\section{Recommended Citation}

Dowdeswell, Tracey Leigh and Hania, Patricia (2014) "Regulating Water and War in Iraq: A Dangerous Dark Side of New Governance," Indiana Journal of Global Legal Studies: Vol. 21 : Iss. 2 , Article 3.

Available at: https://www.repository.law.indiana.edu/ijgls/vol21/iss2/3

This Article is brought to you for free and open access by the Law School Journals at Digital Repository @ Maurer Law. It has been accepted for inclusion in Indiana Journal of Global Legal Studies by an authorized editor of Digital Repository@Maurer Law. For more information, please contactrvaughan@indiana.edu.

\section{$\Psi$}

JEROME HALL LAW LIBRARY

INDIANA UNIVERSITY

Maurer School of Law
Bloomington 


\title{
Regulating Water and War in Iraq: A Dangerous Dark Side of New Governance
}

\author{
Tracey Leigh Dowdeswell \& PATRICIA HANIA*
}

\begin{abstract}
In the legal scholarship, the 'new governance' mode of governance advances an administrative arrangement where decision-making is shared amongst a range of actors, both public and private. The flexible, responsive, and collaborative governance orientation is intended to counter the ill effects of a coercive, top-down, state-centric, commandand-control approach to governance. Critics contend the new governance framework can displace the interests of local communities, disempower individuals, and dislodge basic human rights. The U.S. military has adopted such an adaptive approach in its own governance structure, which in this article is referred to as: the new governance "mentality." This mentality of governance was employed in the U.S.'s post-conflict reconstruction efforts in Iraq-efforts that were plagued by waste, inefficiency, and corruption. Governance scholars have yet to ask the question of what models of governance should apply in the post conflict situation where the environmental violence of war has poisoned waterscapes and degraded landscapes. Should an adaptive mode of new governance be applied in post conflict situations where public institutions are weak and beset by corruption? What is the role of the state and private actors when the war is over and the reconstruction period begins? In this article, we explore a dark side of the new governance framework through the case study of the Iraq war theatre

* Tracey Leigh Dowdeswell and Patricia Hania are both PhD Candidates at Osgoode Hall Law School, York University, Toronto. We would like to thank Professor Alfred Aman for his encouragement and support of our presentation of this paper at the Law and Society Association Annual Conference "Power, Privilege, and the Pursuit of Justice: Legal Challenges in Precarious Times" (Boston, 2013). We would also like to give thanks for the generous comments provided by the peer reviewers and the IJGLS editorial team, in particular, Jia Li (Editor-in-Chief), Lydia Barbash-Riley, and Daniel Cyr. Finally, our thanks to our home institution-Osgoode Hall Law School's graduate program-and, its support of critical, interdisciplinary research and a desire to uphold Tentanda Via: The way must be tried.
\end{abstract}

Indiana Journal of Global Legal Studies Vol. 21 \#2 (Summer 2014)

(C) Indiana University Maurer School of Law 
and examine how the transformed military culture shaped the 20032013 Coalition operations in Iraq and the reconstruction effort-in particular, the provision of safe, clean drinking water to local communities.

\section{INTRODUCTION}

The "new governance" model, advanced by legal scholars, promotes an administrative arrangement in which decision-making is shared among a range of actors, both public and private. ${ }^{1}$ Often, this relationship is privatized and controlled by the terms of a contract. This flexible, responsive, and collaborative governance orientation is intended to counter the ill effects of a coercive, top-down, state-centric, command-and-control style to governance. Critics contend the new governance framework can displace the interests of local communities, disempower individuals, and dislodge basic human rights. ${ }^{2}$

Recently, military organizational scholarship has documented a shift in the army's governance to an adaptive mode. ${ }^{3}$ This flexible mode of governance recognizes that "[t]oday's army is fighting a new kind of war that demands a new approach to how it trains, equips, and uses soldiers." 4 In support of this organizational change, junior officers and soldiers on the ground are expected to be responsive to the local situation and must "make quick decisions, learning through trial and error and sometimes departing from standard Army procedures." 5 Captain Nicholas Ayers, who led a unit in Iraq, described this reactive practice of decision-making, where he was expected "to come up with new solutions to situations the Army had never before encountered."6

1. See, e.g., ThE OXFoRd HANDBOOK OF Governance (David Levi-Faur ed., 2012) [hereinafter THE OXFORD HANDBOOK OF GOVERNANCE]; Orly Lobel, The Renew Deal: The Fall of Regulation and the Rise of Governance in Contemporary Legal Thought, 89 MinN. L. REv. 342 (2004); Lester M. Salamon, The New Governance and the Tools of Public Action: An Introduction, in THE TOOLS OF GovernmenT: A GUIDE TO THE NEW GOVERNANCE 1 (Lester M. Salamon ed., 2002).

2. Douglas NeJaime, When New Governance Fails, 70 OHIO ST. L.J. 323, 333 (2009). See also Lisa T. Alexander, Reflections on Success and Failure in New Governance and the Role of the Lawyer, 2010 WIS. L. REv. 737 (2012); Lisa T. Alexander, Stakeholder Participation in New Governance: Lessons from Chicago's Public Housing Reform Experiment, 16 GEO. J. ON POVERTY L. \& POL'Y 117 (2009).

3. ChaD C. Serena, A Revolution in Military adaptation: The US ARMy in the IRAQ WAR 47-48 (2011).

4. Richard L. DafT, ORganization Theory and Design 28 (9th ed. 2007) (referencing Greg Jaffe, Trial by Fire: On Ground in Iraq, Capt. Ayers Writes His Own Playbook, Wall St. J., Sept. 22, 2004, at A1).

5. Id.

6. Id. 
This responsive mode of governance reflects a new mentality (or culture) for the military that is coined in this article as the U.S. Military's "new governance mentality"-a mentality that is defined as an adaptive, devolved, decision-making model.

But what is not new for soldiers is the environmental violence of war-the strategic use of the environment as a target. ${ }^{7}$ While in the fog of war, where the soldier is disconnected from the environmental impact of his or her actions upon local citizens and communities, this shift to a new governance mentality is dangerous because it may be permissive of human rights violations and creates an environmental injustice situation in the post-conflict scenario. ${ }^{8}$ Governance scholars have yet to ask the following questions: What model of governance should apply in the post-conflict state, where the environmental violence of war has poisoned waterscapes and degraded landscapes? Is a responsive and adaptive mode of new governance appropriate in the post conflict setting? Furthermore, what are the roles of state and private actors, including corporations and non-governmental organizations, when the war is done and the reconstruction period begins?

Interestingly, the organizational development business literature has also documented a governance shift as demonstrated by the "dismantling of the bureaucratic-hierarchal" architecture of firms "to introduce a flatter, more responsive [organizational] structure; and reengineered business processes."9 Homogeneity in governance forms and values has emerged from the business, military, and governance literatures. What does this overlap in theory tell us about the danger of transplanting a new governance mentality into a post-conflict situation, its impact on decision-makers, and "on the ground" decision-making practices?

In a post-conflict setting, particularly in former colonial territories such as Iraq in which governance institutions may be very weak or non-

7. See generally DAVID E. MOSHER ET AL., GREEN WARRIORS: ARMY ENVIRONMENTAL Considerations for Contingency Operations from Planning Through PostCONFLICT (2008), http://www.aepi.army.mil/docs/whatsnew/RAND_MG632.pdf [hereinafter GREEN WARRIORS]

8. Id.; A post-conflict situation is often referred to as "stability," "reconstruction," and "nation-building" activities. see also RAND CORP., THE ARMY's GREEN WARRIORS: ENVIRONMENTAL CONSIDERATIONS IN CONTINGENCY OPERATIONS (2008), http://www.rand.org/content/dam/rand/pubs/research_briefs/2008/RAND_RB9335.pdf (a research brief for GREEN WARRIORS, supra note 7).

9. John Hassard et al., Managing in the New Economy: Restructuring White-Collar Work in the United States, the United Kingdom, and Japan, in 21ST CENTURY MANAGEMENT: A REFERENCE HANDBOOK 65, 66 (Charles Wankel ed., 2008) [hereinafter Managing the New Economy]. 
existent, ${ }^{10}$ the influence of the U.S. military's new governance mentality highlights the deficiencies of these private-public governance arrangements where private actors are transformed into regulators of public services. In this article, we explore a dark side of the new governance framework through the case study of the Iraq war theatre and the water sector. We examine how the transformed military culture shaped the 2003-2013 Coalition operations in Iraq and the reconstruction effort-in particular, the provision of safe, clean drinking water to local communities. While the U.S. Army has actively participated in restoring local drinking water, sewer, electricity, and trash services, ${ }^{11}$ the RAND Institute has reported: "[T]here is a lack of attention to and consideration for environmental issues in contingency operations through much of the Army. Many Army personnel assume environmental considerations are someone else's responsibility." 12

Accordingly, we question whether the military's new governance mentality augmented the army's lack of an environmental ethos throughout its theater of military operations in Iraq. ${ }^{13}$ The weak and ineffective reconstruction campaign not only points to a failure to

10. See, e.g., Nelida Fuccaro, Ethnicity, State Formation, and Conscription in Postcolonial Iraq: The Case of the Yazidi Kurds of Jabal Sinjar, 29 INT'L J.L. MIDDLE E. STUD. 559 (1997) (discussing the shaping of postcolonial Iraqi society).

11. It is reported that "after the Army helped repair a well in Iraq, an Iraqi citizen said, 'When this well is done, each time somebody takes a drink of water they will say the Americans did something good."' GREEN WARRIORS, supra note 7, at 119. It is noteworthy that insurgency activities seem to be highest in areas of weak water, sewer, electricity and trash service:

Evidence from operational experience in Iraq suggests that environmental problems may contribute to insurgency problems. From fall 2003 throughout 2004, the 1st Cavalry Division, under the command of Major General Chiarelli, developed, managed, and worked on numerous SWET [sewer, water, electricity and trash] projects in Baghdad, including cleaning and repairing clogged sewer lines, collecting trash, and building a new landfill. Using Geographic Information System (GIS) databases and tools to analyze geospatial patterns, General Chiarelli's intelligence officers determined that the insurgency was strongest in areas with little or no sewer service, faltering electricity, and high unemployment. Addressing sewer, trash, drinking-water, and electricity issues was important for the "fence sitters" who had not yet decided whether to support the new government or the insurgency. These poor or barely middle-class Iraqis who often do not have jobs are prime recruitment pools for the insurgents. General Chiarelli contends that by giving them jobs and helping to address SWET problems, they will see that the Americans are helping and may decide not to join the insurgency. In fact, the 1st Cavalry Division found that where services were restored, insurgent attacks fell sharply."

Id. at $119-20$.

12. Id. at 103 .

13. Id. at $103,111$. 
empower local governance, but also amplifies conflict-induced environmental harms-an environmental injustice situation where local communities are left to live with the insidious eco-health effects created by war and its environmental legacy. Governance scholars must consider whether the adoption of new governance mentalities of privatization, decentralization, fallibility, and devolved decision-making hamper our ability to protect socio-economic rights and the environment during war and in the post-conflict reconstruction period. ${ }^{14}$

In this article, we examine the new governance framework as applied in the modern U.S. Military. Part I outlines the core principles of the new governance mentality. Part II presents the new governance mentality adopted by the U.S. military during the "revolution in military affairs" as it sought to restructure the U.S. Army in the postCold War era. Part III discusses the old governance mentality of command-and-control established in Iraq by the British during their World War I campaign, which provides a point of reference to understand the reconstruction efforts undertaken in Iraq in the past decade. Part IV outlines the environmental degradation in Iraq because of the 2003 invasion, partly due to the use of chemical weapons and military tactics during the Coalition campaign. ${ }^{15}$

\section{The New GovernanCE MENTAlity}

The new governance model is viewed in part as a reaction to the traditional command-and-control style to governing, ${ }^{16}$ and a response to the trend of deregulation and privatization of the neo-liberal era that

14. See Int'l Comm. of the Red Cross, Protocol Additional to the Geneva Conventions of 12 August 1949, and Relating to the Protection of Victims of International Armed Conflicts (Protocol I) art. 51(3), Jun. 8, 1977, 1125 U.N.T.S. 3 (stating that the intentional targeting of civilians in armed conflict is specifically prohibited under international law); Rome Statute of the International Criminal Court art. 8(2)(b)(i), July 17, 1998, 2187 U.N.T.S. 90 (stating that it is a war crime to intentionally direct an attack against any civilian not taking a direct part in hostilities). See GREEN WARRIORS, supra note 7, at 158163 , for a listing of international law and treaties that relate to the environment.

15. See generally SABYa Farooq et. al., Medact, ContinUing Collateral DaMage: The Health and Environmental Costs OF WAR ON IRAQ 2003 (Jane Salvage ed., 2003), http://www.ippnw.org/pdf/medact-iraq-2003.pdf [hereinafter MEDACT REPORT].

16. For some of the many descriptions of the new governance model (NG) in the literature, see, for example, Bradley C. Karkkainen, "New Governance" in Legal Thought and in the World: Some Splitting as Antidote to Overzealous Lumping, 89 MINN. L. REV. 471, 474 (2004) (describing new governance as "open-textured, participatory, bottom-up, consensus-oriented, contextual, flexible, integrative, and pragmatic"); and Neil Walker \& Gráinne de Búrca, Reconceiving Law \& New Governance, 13 ColUM. J. EUR. L. 519, 520 (2007) (contending that "causal analyses" of law and NG are insufficient because they fail to reveal how NG shapes law and how law shapes NG with modern regulatory regimes). 
shifted the boundaries connecting the public and the private spheres. ${ }^{17}$ Contemporary governance has been reshaped by the managerial ideology of the New Public Management (NPM) that gained influence beginning in the $1980 \mathrm{~s},{ }^{18}$ and then by the later adoption of the new governance framework. Some scholars contend the new governance approach brought in a "cluster of new . . . values"19 that under some organizational structures can advance a neo-liberal corporate orientation into the public law arena.

The nation-state and the idea that effective control is maintained by a centralized, bureaucratic chain of command ${ }^{20}$ has been transformed by the new governance paradigm. Governance scholar Neil Gunningham contends that "[n]ormatively, new governance is claimed to be more responsive, legitimate, and effective than top-down approaches because deliberation, cooperation, and learning at the local level may lead to responses which better take account of local circumstances, build on local knowledge and capacities[.]"21 The role and function of the state has shifted from a command-and-control implementation style to more of an orchestrator of a participatory and localized mode of governance.

The features of decentralization, privatization, a minimal state, and corporate or "entrepreneurial" governance and self-organizing systems rather than centralized and top-down management inform the new governance model. ${ }^{22}$ Like NPM, the collaborative orientation of the contemporary new governance framework is directed at learning, information gathering, and coordination of actors based upon the assumption that the "state and government agencies [could] learn from the practices of private organizational models and market-based management theories." ${ }^{23}$ In this way, the new governance mentality

17. See generally Jon Pierre, Governance and Institutional Flexibility, in THE OXFORD HANDBOOK OF GOVERNANCE, supra note 1, at 187.

18. See generally David OSBORne \& TED GaEbleR, REINVENTING GovernMENT: How THE ENTREPRENEURIAL SPIRIT IS TRANSFORMING THE PUBLIC SECTOR (1992).

19. Chris Tollefson et al., Symposium Overview: Conceptualizing New Governance Arrangements, 90 PUB. ADMIN. 3, 6 (2012).

20. Gareth Morgan, CREative ORganization Theory: A Resourcebook 49 (1989).

21. Neil Gunningham, The New Collaborative Environmental Governance: The Localization of Regulation, 36 J.L. \& SoC'Y 145,146 (2009).

22. R. A. W. Rhodes, The New Governance: Governing Without Government, 44 POL. STUD. 652, 653 (1996).

23. Orly Lobel, Renew Deal: The Fall of Regulation and the Rise of Governance in Contemporary Legal Thought, 89 MrNN. L. REV. 342, 365-66 (2004) Thereinafter Renew Deall. See also Orly Lobel, New Governance as Regulatory Governance, in THE OXFORD HANDBOOK OF GovernANCE, supra note1, at 65. For a response to Renew Deal, see generally Karkkainen, supra note 16, and for Lobel's reply to Karkkainen, see generally Orly Lobel, Setting the Agenda for New Governance Research, 89 MINN. L. REv. 498 (2004). 
subsumes and creates space for a range of privatization principles: efficiency, flexibility, and decentralized decision-making.

The new governance framework also advances a mentality of participation and partnership that includes a range of actors. The governance exercise becomes one of a shared "normative authority" 24 amongst levels of authority and decision-makers with diverse outcome expectations. Decision-making becomes a collaborative task.

Collectively, decision-makers become norm generators, as these individuals "are involved in the process of developing the norms of behavior and changing them." 25 This collaborative partnership involves promoting horizontal-as opposed to hierarchical-relationships, with the effect of blurring private and public values. In this shared decisionmaking mode, we might see the private sector becoming regulators of public resources such as the public water system. The active participation of the private sector may result in traditional government functions being dispensed to a diverse array of private actors.

Experimentation-a willingness to innovate and a tolerance for failure-is a feature of the new governance framework. ${ }^{26}$ Conceptually, experimentation is tied to the principle of subsidiarity, which "maintains that all governmental tasks are best carried out at the level closest to those affected by them." 27 Given the new governance mentality has a strong focus on the importance of information management, the subsidiarity principle highlights the importance of local information, in particular, "[t]hose closest to the problem [who] possess the best information leading toward a potential solution." 28 With subsidiarity, devolved decision-making is fostered, as is collaboration, which together underpin the principles of flexibility and fallibility.

Flexibility and non-coerciveness are intended to replace "top-down ordering, implementation, and enforcement" 29 with negotiable and revisable norms. In effect, a subtle move away from sanctions and penalties of the command-and-control regime promotes a new organizational ordering. ${ }^{30}$ Instead, the new governance framework upholds individual choice and freedom of action, ${ }^{31}$ although this freedom may not be evenly distributed among all actors: "[it] is often better to allow a range of interpretation, deviance, and trial and error without

24. Renew Deal, supra note 23 , at 373 .

25. Id. at 377 .

26. See id. at $381-82$.

27. Id. at 382 .

28. Id.

29. Id. at 388 .

30. See id. at 391.

31. Id. at 389 . 
the constraints of rigid orders and fear of formal sanctions." 32 In other words, experimentation in decision-making is encouraged.

The laissez-faire orientation underpinning the turn to the new governance model fosters fallibility, adaptability, and dynamic learning. ${ }^{33}$ Fallibility means that actors are "optimistic about uncertainty and doubt" 34 as governance is a learning process rather than a social-ordering task. ${ }^{35}$ This idea of experimentation creates institutional space for accepting mistakes, which are also viewed as learning opportunities rather than failures. ${ }^{36}$

In essence, the new governance project is one of "institutional change." 37 The new governance framework results in an organizational restructuring that takes into account how to govern from the ground up: that is, in a participatory, pluralistic, and localized mode where a flatter, adaptive, self-regulatory organizational structure emerges from the attributes of new governance. The normative framework creates an institutional culture that supports devolved decision-making and is reactive to local conditions on the ground; it fosters the freedom to make decisions; it breaks down the rigid, hierarchal information channels established under a state centered governance approach; and it reorients the centralized roles and functions of the state to support a network governance approach. Yet, the question of whether the new governance model is effective in a post-conflict situation remains open, and relatively unexplored.

New governance experiments have been explored in numerous spheres including the area of social regulation, for example environmental protection. Similarly, modern organizational development theory purports similar attributes of responsiveness, flexibility, and changeable environment in response to an organizational theory shift away from a hierarchal, command-and-control structure to a more networked, flatter, self-regulatory organizational form. ${ }^{38}$ Today, global firms by "downsizing and delayering" have reordered their bureaucratic management systems "in order to cut costs, speed up decision making" and "become more flexible and responsive to customer demands and competitive pressures." 39 The U.S. military also offers an example of a recent organizational change campaign that shifted its

32. Id. at 393 .

33. Id. at 395 .

34. Id.

35. Id. at 396.

36. Id. at 399.

37. Amy J. Cohen, Negotiation, Meet New Governance: Interests, Skills, and Selves, 33 J.L. \& SOC. INQUIRY 503, 503 (2008).

38. MORGAN, supra note 20.

39. Managing the New Economy, supra note 9, at 66. 
culture toward a more adaptive, devolved decision-making model or what this article refers to as new governance mentality. ${ }^{40}$

A danger of the new governance paradigm, especially in armed conflict, is the loss of personal liberty and an individual's ability to maintain one's well-being, issues fundamentally tied to protecting the natural environment. ${ }^{41}$ Governance scholar Orly Lobel warns, "we must consider the ever-changing predicament of liberty, and the ever new methods by which it may be augmented and curtailed." 42 The prime goal of security governance - whether in a military or domestic post conflict situation-is the use of coercion and the threat of coercion to maintain social order. Lobel's warning points to a dark side of this governance approach and a mismatch in governance norms (in particular, new governance mentality: devolved decision-making with the new governance mentality and coercive techniques with security governance mechanisms). While the performance of governing is exhibited by the soldier's devolved decision-making practices promoted by the new governance mentality, coercion is the preferred method used to carry out the security governance goals. In a post-conflict situation, achieving good environmental governance practices is complicated by the competing interest of maintaining security through coercion, which exposes the precarious state of personal liberty and leaves unclear the environmental consequences of this adaptive mode of governance.

40. See generally SERENA, supra note 3; Ben Barry, Adapting in War, 54 SURVIVAL: Global Pol. \& Strategy 171, 174 (2012) (reviewing Williamson Murray, MilitaRY ADAPTATION IN WAR: WITH FEAR OF CHANGE (2011)). Barry states: "Command and tactics have become ever more decentralised and dispersed, amplifying the difficulties posed by wars' inherent frictions. And the ever-increasing need for bureaucratic systems of managing armed forces in peacetime - essential for efficiency, logistics and administration - often act to inhibit flexibility and adaptation in war." Barry's comments highlight the need to consider the governance orientation in time of war and times of peace or peace making; See also DAFT, supra note 4. Daft states: "Many organizations are shifting from strict vertical hierarchies to flexible, decentralized structures that emphasize horizontal collaboration, widespread information sharing and adaptability. This shift can clearly be seen in the U.S. Army, once considered the ultimate example of a rigid, top-down organization. Today's army is fighting a new kind of war that demands a new approach to how it trains, equips, and uses soldiers. Fighting a fluid, fast-moving, and fast changing terrorist network means that junior officers in the field who are experts on local situation have to make quick decisions, learning through trial and error and sometimes departing from standard Army procedures. . . 'This is entirely a bottom-up war,' says Major John Nagl, third-in-command of a battalion near Fallujah Iraq. 'It is the platoon leaders and commanders that are fighting it."

41. GREEN WARRIORS, supra note 7, at 9 ("[D]uring summer 2004, diseases such as typhoid and hepatitis were rampant in Baghdad. Supplying clean drinking water is therefore a key reconstruction priority in such areas.").

42. Renew Deal, supra note 23 , at 357. 


\section{THE U.S. MILITARY's ORGaniZATIONAL GOVERNANCE STRUCTURE AND THE EMERGENCE OF A NEW GovernanCE MENTALITY}

The modern military culture has been characterized as flexible, innovative, and responsive to surprise and uncertainty. General Eric Shinseki described the modern military as a "transformed army [that] would be more responsive, deployable, agile, versatile, lethal, survivable, and sustainable than the pre-transformation force and that the strategic flexibility inherent to the objective force would enable dominance at 'every point on the spectrum of operations." 43 This shift in the military's governance culture began in the late $1980 \mathrm{~s}$ with the end of the Cold War, the changing global economic order, and the need to adapt to economic processes of globalization. ${ }^{44}$

In its drive to restructure and respond to the challenges of the postCold War era, the U.S. military adopted many of the new governance attributes. Arguably, the military's reorganization is expressed by the shift away from command-control doctrines and the influence of the "Intent-Based Orders" 45 and "Standing Rules of Engagement, 46 which were shaped to adopt the features of a modern organization transformed in line with new governance mentalities. These new military doctrines devolve decision-making onto individual soldiers, which increases the risk that a solider could use lethal force against local civilians and within their communities. One might inquire whether, in the haze of war, individual soldiers thus empowered consider the environmental impact of their decision-making on citizens' well-being and a civilian's capacity to flourish in the future. The question is raised: Does a solider consider the impact of security forces' presence on a citizen's capacity to engage in decision-making in post-conflict governance institutions?

43. SERENA, supra note 3.

44. See, e.g., U.S. ARMY TRAINING AND DOCTRINE COMMAND, ARMY 21: A CONCEPT FOR THE FUTURE: UMBRELLA CONCEPT (1988); YOAV BEN-HORIN \& BENJAMIN SCHWARZ, ARMY 21 AS THE U.S. ARMY'S FUTURE WARFIGHTING CONCEPT: A CRITICAL REVIEW OF APPROACH AND ASSUMPTIONS (1988); STEVEN METZ \& JAMES KIEVTT, THE REVOLUTION IN MILITARY AFFAIRS AND CONFLICT SHORT OF WAR (1994); WILLIAM E. ODOM, AMERICA'S MILITARY Revolution: Strategy and StruCture AFter the Cold WaR (1993); Stephen Peter ROSEN, WINNING THE NEXT WAR: INNOVATION AND THE MODERN MILITARY (1991). See also RAND CORP., MODERN DECISION SCIENCE SUGGESTS NEW METHODS AND TOOLS TO SUPPORT MILITARY DECISIONMAKING (2005), available at http:/www.rand.org/content/ dam/rand/pubs/research_briefs/2005/RAND_RB177.pdf; GREEN WARRIORS, supra note 7.

45. "Intent-based orders" are commands to perform a mission without specifying how it is to be accomplished. See U.S. DEP'T OF DEF., DEPARTMENT OF DEFENSE DiCTIONARY OF MILITARY AND ASSOCIATED TERMS 46 (2014), http//www.dtic.mil/doctrine/new_pubs/jp1_02.pdf.

46. "Rules of Engagement" are standing directives that specify the circumstances under which soldiers will engage in combat activities and use force in a combat zone. Id. at 240-41. 
Under traditional military doctrine, soldiers were bound by a rigid command structure, including a hierarchical chain of command with decision-making centralized in the apex of the command structure. This system of centralized command-control also applied to soldiers fighting in counterinsurgent and unconventional operations that often formed the bulk of day-to-day soldiering. 47 The traditional centralized and hierarchical concepts of command-control required unity of command: that is, a single, clearly defined commander responsible for each operation, and a hierarchical, clear, and unequivocal command structure. ${ }^{48}$ Under this traditional organizational structure, command is centralized with a senior commander issuing all orders.

By the late 1980 s, this centralized chain of command was rapidly becoming obsolete to make room for a new governance mentality-to reiterate, a mentality that is defined as an adaptive, devolved, decisionmaking model. The US military began to institutionalize Intent-Based Orders and Standing Rules of Engagement that, in effect, decentralized the chain of command and pushed decision-making down to the lowest level-the soldier on the ground, as experienced by Captain Nicholas Ayers in Iraq. ${ }^{49}$ Under Intent-Based Orders, individual soldiers are expected to rely on their initiative and personal judgment to determine how best to meet their overall mission assignments as they are only informed of the mission's goals, not instructed how to accomplish the mission.50 Similarly, Rules of Engagement permit soldiers' broad discretion, for example, in using lethal force. ${ }^{51}$ Together, the introduction of Intent-Based Orders and Rules of Engagement signaled a shift in military doctrine to a new governance mentality.

As the literature well documents, the new governance mentality had achieved a significant degree of institutionalization before the U.S. launched its 2003 invasion of Iraq. ${ }^{52}$ Francis Fukuyama and Abram N.

47. See U.S. MARINe CoRPS, SMALl WaRS MANUAL 36 (1940).

48. Dep't of Nat'L Def., CFJP 01: Canadian Military Doctrine 5-3 (Victor A. McPherson et al. eds., 2009) (Can.).

49. See DAFT, supra note 4.

50. See Matthew L. Smith, The five Paragraph Field Order: Can a Better Format be Found to Transmit Combat Information to Small Tactical UNits? 15 (1988). See also Tracey Dowdeswell, How Atrocity Becomes Law: The Neoliberalisation of Security Governance and the Customary Laws of Armed Conflict, 6 J. CRITICAL GLOBAL STUD. 30, 41-44 (2013) (providing an overview of these issues in greater depth by one of the authors).

51. See Dowdeswell, supra note 50, at 44.

52. See, e.g., Francis Fukuyama \& Abram N. Shulsky, Military Organization in the Information Age: Lessons from the World of Business, in THE CHANGING RolE OF INFORMATION IN WARFARE 327 (Zalmay Khalilzad et al. eds., 1999); Eitan Shamir, The Long and Winding Road: The US Army Managerial Approach to Command and the Adoption of Mission Command (Auftragstaktik), 33 J. STRATEgIC STUd. 645 (2010). For 
Shulsky, leaders in advocating organizational change in the U.S. military, drew heavily on modern organizational management theory to argue for the reorganization of the military along corporate lines. ${ }^{53}$ In their view, the U.S. military could benefit from the lessons learned during the restructuring of commercial organizations. ${ }^{54}$ These scholars promoted a reorganization strategy that envisioned a flatter organizational structure, decentralized decision-making, networks, information linkages, experimentation, and the freedom to fail.

Fukuyama and Shulsky envisioned a shift in the military organization towards new technologies-principally, technologies of governance. 55 These scholars argued for new communications and information management systems that paralleled those adopted by corporations: private companies that had already moved towards flatter, more agile, and adaptive self-organized organizational structures. In their view, the military should improve information efficiencies by adopting a "Wal-Mart'-type system of logistics" and supply chain management. 56 Flattening organizational structures improves information flow, as Kodak demonstrated during its restructuring in the 1990s. ${ }^{57}$ These scholars contend military culture should advance innovation and creativity by pushing responsibility downward and outward as experienced by many high-tech companies in Silicon Valley. ${ }^{58}$

In procurement, Fukuyama and Shulsky recommended the military develop relationships with private firms. The military should contract with firms on a "sole source" basis to tap into "private industry's ability to operate quickly and flexibly." 59 These authors hoped that this relational focus would foster a close partnership between the program office and the private contractor, further familiarizing military officers with "commercial practices."60 In effect, privatization norms would be relied upon to subtly shape the military's procurement sector.

the US military's treatment of these issues, see, for example, WILLIAM K. BABB, FUTURE United States Military Organizational StruCture (2001); TIMOThy F. Watson, AMERICAN CENTuRIons: DEveloping U.S. ARMY TACTICAL LEADERSHIP FOR THE TWENTYFIRST CENTURY (2002).

53. FRANCIS FUKUYAMA \& ABRAM N. SHULSKY, THE "VIRTUAL CORPORATION" AND ARMY Organization (1997) [hereinafter THE VIRTUAL Corporation]. The United States Department of Defense sponsored this study.

54. Id. at $\mathrm{i}$.

55. Id. at ix.

56. Id. at xiii.

57. Id. at 9.

58. Id. at 16 .

59. Id. at 70 .

60. Id. This is an apt description of the United State's relationship with Halliburton KBR during the Iraq War. 
The military's rationalized bureaucratic organizational design is viewed as a relic of Max Weber's industrial age. ${ }^{61}$ Modern organizations, like the military, should be more spontaneous. In line with this theme of spontaneity, Fukuyama and Shulsky advocated for the military's organizational structure to be "designed in more of the self-organizing fashion of biological systems, rather than being conceived as elaborate mechanical systems designed and controlled from the top."62 The modern information age required "new forms of organization and completely redesigned processes." 63 In short, they argued that the U.S. military could benefit from the experience of private corporations in adapting to the revolutions engendered by information technologies and economic globalization. ${ }^{64}$

Like private corporations, these scholars maintained that the U.S. military should institutionalize fallibility and the "freedom to fail" so that it might "foster an adaptive and innovative culture."65 Even serious failures can be overlooked "when they are seen as resulting from the taking of reasonable risks." 66 According to these authors, the constraints of a centralized governance regime were to be discarded under the military's new governance mentality.

Specifically, in military maneuvers, Fukuyama and Shulsky reasoned that a flatter, more decentralized command structure could improve strategic battle command: a flat organizational structure promotes making decisions "rapidly, decisively, [and] stealthily."67 In their view, the traditional emphasis on centralizing the chain of command was rooted in the bureaucratized institutional culture of the U.S. military, not its functionality in battle. ${ }^{68}$ Missing in their critique, however, is evidence that decentralization and Intent-Based Orders are, in fact, more functional - that is, responsive to the changing conditions of battle while protecting individual liberty and a civilian family's ability to flourish.

Fukuyama and Shulsky's promotion of a flatter institutional perspective is also advanced by organizational theory and reinforced by the new governance model, which leaves one wondering if the new

61. See generally MORGAN, supra note 20; see also DAFT, supra note 4. Daft notes: "[T] he U.S. Army, [was] once considered the ultimate example of a rigid, top-down organization." It embodied an organizational design displaying the classic features of Max Weber's bureaucracy.

62. The VIRTUAL CoRPoration, supra note 53 , at 70.

63. Id. at 5 .

64. Id. at 4 .

65. Id. at 77 .

66. Id. at 78 .

67. Id. at 46 .

68. Id. at 45 . 
governance mentality is essentially an idea-a by-product of neoliberal ideology. Perhaps it is an idea detached from the soldier's experience in combat and the consequences of individual decision-making in the complicated, hyper-intense situation of the battlefront; an isolating, complex situation that separates the solider from the natural environment and where the fog of war can distort one's moral decisionmaking.

In adopting Fukuyama and Shulsky's vision, the military must also incorporate an ethic of environmental care at the institutional level. While to some, it might seem counterintuitive to demand an institution with a mission statement tied to war to advance an ethic of environmental care especially during a military campaign, to others, the military should be a moral institution. While recognizing the complicated situation of the fog of war, the military's organizational culture should move toward an institutionalized environmental awareness or conscience based on the concept of corporate social responsibility: a concept that advances the "core values of our [globalized] society - respect for quality of life, the environment and human dignity." 69 In light of the military's organizational shift to a new governance mentality, we ask: Who pays the price for the war's sinister, slow-moving environmental harms? The military's adoption of the new governance mentality to frame it's organizational change model must find space to incorporate core values-respect for quality of life, the environment, and human dignity-and acknowledge that the natural environment is transformed into a strategic weapon of war. As a weapon of war, environmental warfare results in mass environmental destruction that creates a precarious eco-health situation for those civilian communities left to clean up the toxic mess.

Interestingly, the characteristics of General Eric Shinseki's modernized military seem to easily map onto the features of the new governance model, which raises a host of new questions. While it remains to be seen whether there are good reasons to advocate for

69. Philippa Collins, Ethical Manufacturing, in 21st Century MaNAGEMENT: A REFERENCE HANDBOOK 464 (Charles Wankel ed., 2008) [hereinafter Ethical Manufacturing]. While we recognize that numerous definitions of the concept of corporate social responsibility (CSR) exist, we adopt the view advanced by the European Commission: CSR "refers to companies taking responsibility for their impact on society." Enterprise and Industry, EUROPEAN COMM'N, http://ec.europa.eu/enterprise/policies/ sustainable-business/corporate-social-responsibility/index_en.htm (last visited July 17, 2014). Philippa Collins describes the EU's concept of social responsibility as an "idea that everyone, not just managers and directors, have a responsibility to take action." Collins, supra. According to Collins, CSR is viewed by the European Commission as "vital because it mirrors the core values of our society- respect for quality of life, the environment and human dignity." Collins, supra, at 461. 
devolved decision-making, fallibility, experimentation, and voluntary compliance in a military campaign, we query whether the ready adoption of a new governance mentality is suitable when a post-conflict situation of environmental degradation emerges from the wreckage of war. Serious issues concerning accountability under the new governance framework as related to public sector services arise-in particular, the provision of clean drinking water to civilians-and, raises the question: Is the new governance model appropriate in a post-conflict situation? Alternatively, should the state(s) involved institute a more traditional, state-centric, command-control model of governance for the provision of essential services such as clean, safe drinking water? In order to better address this question, we explore the "old style" of governance laid down by the British during their colonial campaign in Mesopotamia, and how this regime built the foundations for modern Iraq's water infrastructure.

\section{III. “Old Governance:" THE BRITISH CAMPAIGN IN MESOPOTAMIA AND A STATE-CENTRIC MOdel OF WATER MANAGEMENT}

Iraq's natural environment and public waterworks have a long history of being used as strategic weapons during an armed conflict. ${ }^{70}$ This first occurred on a grand scale on the Mesopotamian Front during World War I, and these events helped to lay the foundation for much of modern Iraq's pre-invasion public waterworks. ${ }^{71}$ The British experience in governing Iraq during this period was that of a centralized administration with a command-and-control implementation style of governance. British forces undertook a massive campaign of building waterworks and associated industrial infrastructure as part of their war effort against the Ottoman Empire in Mesopotamia. Iraq's water sector was laid down in this period, and therefore has close connections to empire building, the large-scale industrialization of colonial possessions, and the British form of centralized governance.

By the nineteenth century, state building required a sophisticated bureaucracy to meet the demands of industrialization and colonization in an increasingly complex social environment. The British campaign against the Ottomans on the Mesopotamian Front during World War I is a typical example of this style of governance. The British campaign

70. See generally GREEN WARRIORS, supra note 7, at 3-7 (explaining the use of dams, oil wells, and other natural resources as strategic targets during military conflicts in the Middle East).

71. See generally L.J. Hall, The Inland Water Transport in Mesopotamia xii (R.H.W. Hughes ed., 1921) [hereinafter INLAND WATER TRANSPORT] (describing that a lack of adequate river transport directly resulted in the British army's inability to break the Turkish siege near Amara). 
began with a stunning military defeat of British forces at Kut al Amara. The British identified the lack of modern river transportation as one of the principal causes of their downfall. ${ }^{72}$ With the disastrous siege at Kut coming just a few months after their defeat at Gallipoli, the British forces retrenched at their base at Basra in southern Iraq, reassessed their strategy, and then began an 18-month campaign to build navigable river transportation, ports, bridges, and railroads across southern Iraq. ${ }^{73}$ During this time, the British forces dredged and channeled a navigation route along the 500-mile river system of the Tigris and Euphrates, and built a large fleet of river barges, in order to prepare for their final march to Baghdad in March of 1917. ${ }^{74}$

Expatriate laborers, under the command of the British, built the canals in Basra and irrigation works in the Mesopotamian Marshlands. ${ }^{75}$ Besides focusing on river transport, the strategic military goal included the expansion of agricultural irrigation and fisheries in order to feed the British troops and their labor force. ${ }^{76}$ This strategic reconstruction effort included extensive dredging and land reclamation for irrigation throughout the marshlands. ${ }^{77}$ The British completed the construction of these infrastructure works with a labor force of about 7,100 workers, primarily skilled workers from India and China. ${ }^{78}$ Troop strength during this time was approximately 40,000.79 The British Colonial Army was the primary force waging the Mesopotamian campaign, and most of these troops came from India, Nigeria, and West Africa. The local population also played an important role as pilots of the river fleet that travelled along the Tigris and Euphrates rivers and their many tributaries. ${ }^{80}$

The British public works projects built during the Mesopotamian campaign of World War I exemplify the kind of "old governance" that European armies used in empire-building campaigns. The British administered Mesopotamia as a colony and transplanted their established governance structures that relied upon an organization of government ministries and agencies. One of these was the Department of River Conservancy, which later became Iraq's first Ministry of

\footnotetext{
72. Id. at xvi.

73. Id.

74. Id. at $14-15$.

75. Id. at $115-123$.

76. $I d$. at 36 .

77. Id. at 115-123.

78. Id. at 14 .

79. Id. at 126 .

80. Id. at 81 (explaining that the only pilots available with good experience of the river were Arabs).
} 
Irrigation in 1917.81 At that time, approximately 34,000 employees managed Iraq's ports, river transport, dams, and irrigation systems. ${ }^{82}$ Much of Iraq's water sector infrastructure can therefore be attributed to this period of British control.

In the bureaucratic spirit of routinized and a centralized administrative structure, the British viewed the auditing, accounting, and anti-corruption processes as key administrative oversight measures of the public works projects in the Mesopotamian region. For example, the War Office stated "all officers dealing in any manner with Government funds should submit their statements of accounts to the Superintendent, the whole being submitted by him to the audit authorities at the Base." 83 Comprehensive records of the projects undertaken, including personnel, acquisitions, accounts, and procurements were kept by hand without the assistance of modern information technologies, and were made publically available. ${ }^{84}$ This detailed administrative control allowed the work to proceed efficiently, transparently, and with minimal loss of scant public revenues.

As with present-day Iraq, the security situation in Mesopotamia during World War I was difficult and dangerous, and destruction of public works served as a military tactic. In one of several incidents, Ottoman forces breached the dam at Fallujah during their retreat, flooding the surrounding countryside. In a rebuilding effort, the British repaired the dam and continued to drain the land before building a railroad and retaking the city. ${ }^{85}$ Iraq, thus, has a long history of public water works being used as weapons in armed conflict, which often resulted in a devastated natural environment.

Recent military campaigns in Iraq illustrate that the natural environment and public works projects continue to be used as strategic instruments of environmental warfare. In the war theater, water systems and landscapes are targeted receptacles for strategic "minelaying." 86 The deployment of chemical weapons exposes the hidden yet planned use of the environment in warfare, including the

81. Id. at 25 .

82. Id.

83. Id. at 99 .

84. Id. See in particular the Appendices.

85. Id. at 27.

86. Robert Francis, The Impacts of Modern Warfare on Freshwater Ecosystems, 48 ENVTL. MGMT. 985, 989 (2011) ("Rivers often represent targets for the use of explosives, for example aerial bombing or minelaying, either because settlements are adjacent to rivers, because they are key transportation corridors, or because their associated structures (e.g., bridges, jetties, irrigation channels, hydroelectric dams) are of strategic importance ... . Use of ordnance can have both direct and indirect impacts. ...") (citation omitted). 
exploitation of aquatic systems and soils. The research on the environmental effects upon soil and water sources is well documented. 87

Public works projects were a cornerstone of U.S. stabilization and reconstruction operations. ${ }^{88}$ Yet, many of these U.S. projects were plagued by waste, inefficiency, and corruption. This inefficient administration, which emerged from the U.S. military, significantly impeded their ability to complete public water infrastructure projects during the decade-long reconstruction. ${ }^{89}$

Complicating the stabilization and reconstruction period is the U.S. military's institutionalized apathy towards environmental protection. ${ }^{90}$ During combat operations "[v]ery few of the [U.S. military's] strategic activities actually address ecosystem and habitat concerns." 91 Moreover, an insufficient number of U.S. Army policies or doctrines exist that offer direction on environmental issues encountered during armed conflict: "Only one Army manual is dedicated to environmental consideration, and it is not widely used."92 A danger exists that this low priority placed on the protection of the environment has complicated the stabilization and reconstruction efforts. Moreover, this apathetic attitude toward the environment further distances the military from the environmental

87. Giacomo Certini, Riccardo Scalenghe \& William I. Woods, The Impact of Warfare on the Soil Environment, 127 EARTH-SCIENCE REV. 1, 11 (2013). ("[The] physical disturbance [of soils] is often accompanied by chemical contamination, which makes soils unsuitable for production purposes and for supporting human welfare in general. Bombs, in fact, release chemicals that after eventually causing an immediate acute detrimental effect for living organisms can reside in soil to induce subtler, more enduring effects. The introduction by weapons with particularly dangerous chemicals, such as dioxins or radionuclides, may impose indefinite land abandonment and interdiction. Biological weapons, perhaps the most infamous offensive weapons for soils, are the sad repository for the dreadful pathogens potentially usable in warfare or terroristic actions, able to keep these active for a long time or at least conserve their spores.").

88. OFFICE OF THE SPECIAL INSPECTOR GENERAL FOR IRAQ RECONSTRUCTION,

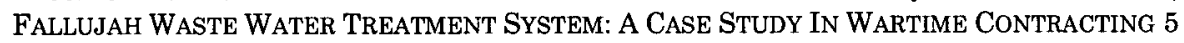
(2011) [hereinafter Fallujah Water Treatment Report], available at http://cybercemetery.unt.edu/archive/sigir/20131001171803/http://www.sigir.mil/files/audit s/12-007.pdf.

89. Learning From Iraq: A Final Report from the Special Inspector General for Iraq Reconstruction 72 (Mar. 2013) [hereinafter SIGIR Report], available at http://cybercemetery.unt.edu/archive/sigir/20131001083907/http://www.sigir.mil/learningfr omiraq/index.html.

90. See GREEN WARRIORS, supra note 7, at 4. The Report points to the military's apathetic attitude toward environmental protection: "As a result, in contingency operations, environmental issues are not given the same priority as force protection and safety and they are generally relegated to base-camp managers, many of whom are Army engineers. Little attention is paid to the strategic implications of the environment on the desired outcome of a contingency." Id.

91. Id. at 101 .

92. Id. at $4,128$. 
effects of its actions upon local communities and a civilian's ability to maintain wellbeing (for example, by accessing basic services such as clean drinking water). In the next section, we argue that the military's new governance mentality contributed to the devastated state of the environment, the difficulties in the reconstruction effort, and Iraq's current lack of potable drinking water.

\section{BOMBS, BOMBLETS, BULLETS \& ENVIRONMENTAL HARMS: U.S. RECONSTRUCTION EFFORTS IN IRAQ, 2003-201393}

\section{A. Water Quality in Iraq Today}

Iraq made significant investments in its infrastructure and public services during the 1970s due to strong oil revenues. Before the 1991 Gulf War, Iraq's water sector was relatively healthy. At that time:

[a]ccess to potable water was 95 percent in urban areas with an average supply of about 330 liters per person per day in Baghdad and about 250 liters per person per day in other cities. Rural water coverage was 75 percent with an average supply of about 180 liters per person per day. ${ }^{94}$

By the time of the 2003 invasion, however, the governing institutions and public works were in poor condition as a result of

93. MEDACT REPORT, supra note 15, at 2-3 (internal citations omitted) ("Cluster weapons contain submunitions called 'bomblets'-explosive projectiles designed to separate and spread when released. When they explode, fragments of munitions penetrate the body, maiming or provoking lethal internal bleeding. This 'fragmentation effect' is an intended design objective. About $30 \%$ of victims die even with good life support. Bomblets are designed to explode on impact, but many fail to explode and become de facto landmines. . . . Depleted uranium (DU) is used in anti-tank ammunition because it is dense and heavy, and penetrates heavy armour. . . L Landmines used by Iraq included anti-personnel (AP) fragmentation mines and blast mines. These cause leg and groin injuries and secondary infections which often lead to amputations, extensive hospital stays and rehabilitation. . . Explosive remnants of war (ERWs) are live munitions left after conflict. From figures published in Hansard ... it is possible to calculate that British cluster weapons alone left between 2,000 and 3,000 ERWs-US ERWs are impossible to estimate owing to incomplete data. Fleeing Iraqi soldiers abandoned large quantities of ammunition, often in easily accessible locations, including 100 Iraqi surface-to-air missiles around Baghdad.").

94. See World Bank, Iraq: Country Water Resource Assistance Strategy: Addressing Major Threats to People's Livelihoods, in Water, Environment, Social and Rural Development Department Middle East and North Africa Region, Rep. No. 36297-IQ, at 35 (June 28, 2006), http://siteresources.worldbank.org/INTWAT/Resources/Iraq.pdf. 
decades of political dislocation, authoritarian rule, the Iran-Iraq War (1980-1988), the bombing campaigns against Iraq during the 1991 Gulf War, and the sanctions and reparations imposed on Iraq for the invasion of Kuwait. ${ }^{95}$ Today, the magnificent Tigris river basin known to biblical scholars as the legendary "Garden of Eden" 96 is no longer a vibrant ecosystem or a healthy source of drinking water..$^{97}$

Historically, the Tigris river basin was known for its biologically diverse ecology, culturally rich social system, and flourishing wetlands. ${ }^{98}$ After the 1991 uprising against the government of Saddam Hussein in southern Iraq that followed the Gulf War, Saddam Hussein drained the Mesopotamian marshlands, killed tens of thousands of Marsh Arabs, and displaced many of the 300,000 to 500,000 Marsh Arabs who once called the wetlands home. ${ }^{99}$ As a result, more than $90 \%$ of the 15,000 square kilometers of ecologically and agriculturally significant wetlands were destroyed. ${ }^{100}$ After the fall of Saddam Hussein in 2003 , locals who were reportedly frustrated at the lack of action took it upon themselves to detonate many of the dams, leading to an uncontrolled re-flooding of the area. ${ }^{101}$ This local response has led to the partial regeneration of the Marshlands, although some scholars have

95. See William R. Polk, Understanding Iraq: The Whole Sweep of IraqI HistoRY, FROM GENGHIS KHAN'S MONGOLS TO THE OTTOMAN TURKS TO THE BRITISH MANDATE TO THE AMERICAN OCCUPATION 128 (2005) (detailing the deterioration of Iraqi public infrastructure due to the eight year Iran-Iraq war).

96. Russell E. Bowman, Student Article, Global Cornerstones for Environmental Recovery in Iraq: A Comparative Law and Policy Analysis of Lessons in Environmental Response and Remediation, 13 N.Y.U. ENVTL. L.J. 501, 508 (2005) [hereinafter Global Cornerstones]; Curtis J. Richardson \& Najah A. Hussain, Restoring the Garden of Eden: An Ecological Assessment of the Marshes of Iraq, 56 BIOSCIENCE 477, 477 (2006) [hereinafter Restoring the Garden of Eden].

97. See United Nations Env'T PRogramme, Desk Study on the Environment IN IRAQ 28-30 (2003), available at http://www.unep.org/pdf/iraq_ds.pdf [hereinafter UNEP REPORT].

The Tigris basin $\left(371,562 \mathrm{~km}^{2}\right)$ covers parts of the territories of Iran (47.2\% of the basin), Iraq (38\%), Turkey (14\%) and Syria $(0.3 \%)$. Within Iraq, the Tigris River receives water from four main tributaries, the Khabour, Great Zab, Little Zab and Diyala, which rise in the mountains of eastern Turkey and northwestern Iran and flow in a southwesterly direction until they meet the Tigris. A seasonal river, Al Authaim, rising in the highlands of northern Iraq, also flows into the Tigris, and is the only significant tributary entirely within Iraq.

Id. at 29. The degradation of the environment of Iraq, therefore, has consequences for other nations and their populations, as well.

98. See generally Global Cornerstones, supra note 96; Restoring the Garden of Eden, supra note 96.

99. Restoring the Garden of Eden, supra note 96 , at 477.

100. Id.

101. Id. at 480 . 
raised concerns that the unplanned rehabilitation of the Mesopotamian Marshlands could agitate an already fragile ecosystem. ${ }^{102}$

Today, many communities continue to rely on the Tigris and Euphrates river system and the marshlands for drinking water, irrigation, and waste management. ${ }^{103}$ Nevertheless, it is not surprising that after numerous armed conflicts these water resources are showing signs of pollution and ecological stress, in part because of the use of chemical weapons and munitions, and other toxic war waste lining the riverbeds and wetlands. Recently, Marshland rehabilitation plans have been put forward; but a concern exists that the uncontrolled re-flooding might adversely affect water quality because "toxins from re-flooded soils that are contaminated with chemicals, mines, and military ordnance"104 could be released. Scientists have expressed concerns regarding the impact of this toxic waste upon vulnerable local communities and an already fragile ecosystem if it is released. ${ }^{105}$

Iraq's precarious state of the natural environment is further compromised by the military's well-documented use of depleted uranium anti-tank ammunition, cluster bombs, and landmines. ${ }^{106}$ Not surprisingly, an increase in incidences of cancer and birth defects in Fallujah subsequent to the 2004 U.S. operations has been reported by non-government organizations. ${ }^{107}$ The United Nations Environmental Program (UNEP) has identified potential health effects on local civilians from the use of explosive and toxic weapons combined with "[m]ilitary waste, including waste from chemical, biological, and nuclear weapons programmes." 108 Currently, the Iraqi countryside is strewn with the artifacts of war-i.e., a variety of toxic munitions and war waste, including: "unexploded ordnance, spent cartridges/shells/penetrators, military vehicles[,] . . . depleted uranium[,] . . . contaminated soils and demolition waste (e.g. containing chemicals or asbestos), [and] human remains and animal remains (leading to elevated disease risks,

102. Id. at 479 .

103. See UNEP REPORT, supra note 97 , at 28.

104. Restoring the Garden of Eden, supra note 96, at 481.

105. Id.

106. MEDACT REPORT, supra note 15, at 2. See also MEDACT, EndURING EFFECTS OF WAR: HEALTH IN IRAQ 2004 (2004). For a discussion of the health effects of uranium munitions in Fallujah, and their link to a higher incidence of a birth defects there, see generally Samira Alaani et al., Uranium and Other Contaminants in Hair From the Parents of Children with Congenital Anomalies in Fallujah, Iraq, ConfliCT \& HEALTH, 2011, at 2-3; Samira Alaani et al., Pilot Study of Congenital Anomaly Rates at Birth in Fallujah, Iraq, 2010, J. IsLAMIC MED. Ass'N N. AM., Aug. 30, 2012, at 1-2.

107. See generally MEDACT REPORT, supra note 15.

108. UNEP REPORT, supra note 97 , at 37. 
especially in urban areas)." 109 Remarkably, even though the production of war artifacts is an expected outcome, the RAND Corporation reported that little attention is given by the military to the "long term health of natural systems, including ecosystems and species" 110 during armed conflicts. Consequently, the military's spent wreckage that now litters Iraq's waterscapes and countryside has created an insidious environmental legacy for current and future citizens.

In Iraq's military theatre, individual soldiers displayed an apathetic, disconnected attitude towards environmental protection. With respect to the discharge of waste in a base camp, a soldier stated: "We are in the desert, what does it matter?," "The locals don't care, so why should we?," and "We are just passing through and don't have the time."111 For a combat soldier, it is reasonable to expect that this institutionalized attitude of disregard for environmental protection would naturally be embraced when the bombs begin to drop and bullets zoom by during chaotic combat. While in-theatre, individual soldiers separate themselves from the natural environment and any environmental impact of their actions. In effect, they lack an environmental ethic during armed "contingency operations." 112

Military instruction also fosters a discharge ethos and has institutionalized a lack of an environmental ethic of care. Military training normalizes the soldier's action that "when firing a round downrange, an artilleryman wasn't 'discarding' the round."113 The soldier's task and his weapon are spent: i.e. done, so, he can now "cut and run."114 This permissive discharge ethos encourages toxic armaments to be abandoned, disposed of, tossed away; distancing the ordinary solider from the effects of discharging his weapons. ${ }^{115}$ The military debris that now litters Iraq's water and land is evidence of this discharge ethos. The indiscriminate dispersal of toxic military armaments across the countryside points to an institutional mindset that releases the environmental violence of its operations onto the

109. $I d$.

110. GREEN WARRIORS, supra note 7 , at 118 .

111. Id. at 103 .

112. Id. at 131 .

113. William A. Wilcox, Jr., The Modern Military and the Environment 46 (2007).

114. John Braithwaite, Relational Republican Regulation, 7 REG. \& GoveRNANCE 124, 141 (2013) [hereinafter Relational Republican Regulation] (explaining the idea of "cut and run," versus an ethical obligation to manage de-escalation).

115. Oddly, even though the discarded munition might be a "safety hazard]" to the solider, the spent armament is not considered to be environmentally harmful. WILCOX, supra note 113, at 46. Although the United States has taken steps to regulate spent munitions on its own soil as hazardous waste, these regulations do not apply when such munitions are used in military operations overseas. Id. at 46-48. 
health of civilians and into the natural environment in which local citizens are expected to live and to flourish socially, culturally, and economically in a post-conflict scenario. ${ }^{116}$

Taken together, the discharge ethos and the responsive, adaptive new governance mentality that transfers the decision-making to the ordinary solider, sets up the solider to lose his connection with the natural environment and the impact of his actions on the human condition. A danger exists that a lack of an ethic of environmental care, at both a high strategic military level and within the soldier's selfregulatory unit, is fostered, and is displayed by an individual soldier carrying out his operational roles. ${ }^{117}$

Currently, many communities in Iraq have limited access to potable drinking water and adequate sewage systems as a result of the violence of war. This governance failure reflects a lack of an environmental ethic, environmental rights, and administrative oversight, which is discussed further below. ${ }^{118}$ Natural sources of drinking water are showing signs of stress, including "salt accumulation problems, toxic elements, and severe water quality degradation," as well as water scarcity.119 A U.S. military campaign targeting industrial facilities and providing limited protection for public works projects has created a vulnerable situation for Iraqi citizens, especially local women and children.

Women and children are particularly vulnerable to toxins because of "critical windows of exposure" to their endocrine systems and limited

116. Rob Nixon, Ecologies of the Aftermath: Precision Warfare and Slow Violence, in SLOW VIOLENCE AND THE ENVIRONMENTALISM OF THE POOR 199 (2011). Nixon argues that the narrative of a precise, smart war needs to be countered and he explains "[w]hat such narratives downplay is the way each war generates a distinctive, historically specific chemical, radio-logical, epidemiological, and environmental legacy." Id. at 209. For example "[t]he turn to depleted-uranium warfare and the unprecedented proliferation of cluster bombs demands that we revisit the question of who counts as a casualty." Id. at 211 Nixon argues that the "the deferred casualties among refugees returning to poisoned, radiated landscape[s]" need to be included in the calculus. Id. "For we need to measure a weapon's 'kill range' not just across the battlefield space but across ecological and genetic time as well." Id. at 213 . Nixon ends his argument with a plea to change the focus to "the slow-moving stories about the long dying . . . about depleted uranium that treats as its arbitrary enemy the child of a child as yet unborn." Id. at 232.

117. GREEN WARRIORS, supra note 7.

118. Sharmila L. Murthy, Iraq's Constitutional Mandate to Justly Distribute Water: The Implications of Federalism, Islam, International Law and Human Rights, 42 GEO. WASH. INT'L. L. REV. 749, 750 (2010); see also UNEP REPORT, supra note 97, at 45; Costs and Consequences of War in Iraq: Fact Sheet 2, CENTER FOR ECON. \& SOC. RTS., http://www.cesr.org/downloads/Costs\%20and\%20Consequences\%20of\%20War\%20in\%20Ir aq.pdf (last visited Apr. 4, 2014).

119. Restoring the Garden of Eden, supra note 96 , at 484 . 
access to governance regimes. ${ }^{120}$ In a healthy natural environment, the transmission of the toxins can occur by either directly ingesting the toxic water or through hand to mouth contact with the soil or breathing in air with toxic dust particles. As expected, in war-ravaged waters and landscapes, toxicity levels are heightened and are present as a particularly risky public health problem for families and individuals in the local community.

Military doctrine pays little attention to fostering an ethic of environmental care, an ethic that should be directed at an ordinary soldier in order to facilitate decision-making that considers the environmental implications of his actions while operating on the ground in the intense, complicated theatre of war. ${ }^{121}$ Sadly, the degraded state of water resources has created an environmental injustice that places the risks of drinking from contaminated water sources on vulnerable civilians while discharging the military of their responsibility for degrading the water source. In economic terms, this environmental degradation is disregarded as an externality (i.e., market failure) of war. ${ }^{122}$

\section{B. "New governance": Corruption and the Coalition Reconstruction of Iraq, 2003-2013}

In 2003, the Coalition Provisional Authority (CPA) banned all members of the Ba'ath Party from holding public service jobs. ${ }^{123}$ The

120. National NETWork on Environments aNd Women's Health, The Gendered HEALTH EFFECTS OF CHRONIC LOW-DOSE EXPOSURES TO CHEMICALS IN DRINKING WATER 14, 31 (2009), http://www.nnewh.org/images/upload/attach/1588hamm\%202009.pdf ("Critical windows of vulnerability have been broadly identified according to developmental and reproductive stages. These stages include preconception, the embryonic and fetal period (pregnancy), the neonatal period, the first three years of life, preschool and school age, and adolescence. In general, the most vulnerable stages are those of fetal and early postnatal development. The developing immune systems of infants and children, their unique behavioural characteristics, and greater exposure patterns result in very different sensitivities to contaminants than in adults. Importantly, the exposure patterns of infants and children also change dramatically as they mature.").

121. GREEN WARRIORS, supra note 7, at 133 (recommending the adoption of a sustainability ethic).

122. See THE QUEST For ENVIRONMENTAL JusticE: Human RightS AND THE Politics OF POLLUTION 1 (Robert D. Bullard ed., 2005) (explaining the now prevalent use of the term "environmental injustice").

123. SIGIR Report, supra note 89, at 105. "Lieutenant General Ricardo Sanchez, Commander of Coalition forces in Iraq from June 2003 to June 2004, later stated that this order 'essentially ...eliminated the entire government and civic capacity of the nation"' See $I d$. The order banning all members of the Ba'ath Party from the public service was CPA Order 1 of 16 May 2003 issued by the head of the CPA, L. Paul Bremer. 
military invasion and the de-Ba'athification program led to a complete collapse of governing institutions and the public sector, which then had to be rebuilt from the ground up. ${ }^{124}$ In March of 2013, Stuart Bowen, the Special Inspector General for Iraq Reconstruction, produced his final report (SIGIR) for the U.S. Congress detailing the inefficiencies, waste, and corruption that led to widespread failures in Coalition reconstruction projects in Iraq. The reconstruction was overseen by a myriad of U.S. and Coalition government agencies, multi-national forces, nascent Iraqi government ministries who often had poor training and resources, hundreds of private contracting companies, and an unknown number of non-governmental organizations, leading the SIGIR Report to ask whether the reconstruction was simply too complex to oversee and police adequately. 125

Research demonstrates that good governance bolsters an individual's sense of well-being, while corruption leads to lower levels of well-being for individuals and, collectively, for communities. ${ }^{126}$ Corrupt practices prevailed during the reconstruction period. SIGIR reported deficiencies among all sectors in record keeping making it impossible to trace programs and accounts. ${ }^{127}$ Among the private companies contracted to undertake construction work, the auditors found inadequate billing records, fraud, abuse, and over-billing-amounting in many cases to mark-ups of thousands of percent for small items. ${ }^{128}$

One failed reconstruction project is the $\$ 100$ million sewage treatment facility in Fallujah. ${ }^{129}$ Following the massive 2004 Coalition operations, the plant was to be built to reassure the city's population of the efficacy and legitimacy of the new Iraqi government. The plant-a flagship project-was an example of a public-private partnership and decentralized planning. The main contract was awarded to the Fluor Corporation of Texas, who subcontracted the work out to various private contractors. Reportedly, the final project cost totaled more than three times the original estimate, and the plant was only partially completed after substantial delays for primarily two reasons: an inability to establish basic security in the city, and a failure by the contractors to establish an adequate electrical power source. ${ }^{130}$ Today, in Fallujah,

124. Id.

125. See generally id. at ix-xii (explaining broadly the costs and issues of the Iraq reconstruction project).

126. WORLD HAPPINESS REPORT 121, 141 (John Helliwell et al. eds., 2013), available at http://www.earth.columbia.edu/sitefiles/file/Sachs\%20Writing/2012/World\%20Happiness\% 20Report.pdf.

127. SIGIR Report, supra note 89, at 74.

128. Id. at 3.

129. Fallujah Water Treatment Report, supra note 88, at 29.

130. SIGIR Report, supra note 89 , at 82. 
children play in the streets where raw sewage flows freely. The city has limited potable drinking water. This degraded environment is considered a significant source of morbidity and mortality among the city residents ${ }^{131}$ and contributes to the reported lack of well-being among Iraqis. ${ }^{132}$

Paradoxically, crude oil production in Iraq is steadily increasing. It is higher than at the end of the Iran-Iraq War in 1988, and is approaching its all-time high of 1979.133 Increasing oil production suggests that state revenues should be increasing, which raises the question: Who is benefiting from these increased revenues? One wonders whether the present reconstruction effort will return the water sector to a healthy state; that is, to a pre-1991 Gulf War public service where "[a]ccess to potable water was 95 percent in urban areas."134

Reestablishing basic water infrastructure and governance in postconflict Iraq has not been a successful endeavor for the Coalition reconstruction campaign. One example is the U.S. reconstitution of the Iraqi Ministry of Irrigation. At the time of the 2003 invasion, the Ministry of Irrigation employed about 12,000 people-less than a third of its labor force in 1917-and contracted with 11 state-owned or linked companies under the direction of the Minister of Irrigation. ${ }^{135}$ After the invasion, the Ministry was looted, leaving its infrastructure in disarray. Stripped of furniture, computers, computer systems, and records, the Ministry had no e-mail, no ability to store databases, no central records to manage payroll, and no human resource records. ${ }^{136}$ The U.S. administration, with the assistance of the U.S. Army Corps of Engineers, restructured the Iraqi's Ministry of Water Resources. ${ }^{137}$ The ideology of the new, reconstructed Ministry included many of the market economy principles of new governance: participatory decisionmaking, reliance on public-private partnerships, deregulation and privatization, and privileging of experimentation and fallibility, such that the new Ministry relied upon techniques and metrics that

131. Id.

132. See WORLD HAPPINESS REPORT, supra note 126, at 141 (observing factors that contribute to insufficient happiness, including services and ecological issues).

133. SIGIR Report, supra note 89 , at 83.

134. WORLD BANK, IRAQ: WATER RESOURCES INTERIM ASSISTANCE STRATEGY 35 (2006), available at http://siteresources.worldbank.org/INTWAT/Resources/Iraq.pdf.

135. Michael J. Bishop et al., Iraq Ministry of Water Resources Capacity Building, DEF. TEChNICAL INFo. Center (Aug. 5, 2005) [hereinafter Iraq Ministry of Water], http://www.dtic.mil/ndia/2005triservice/track4/wilhelms.pdf.

136. Id.

137. Thomas O'Hara \& Eugene Stakhiv, Iraqi Ministry of Water Resources is Similar to Corps, 27 ENGINEER UPDATE (2003), available at http://archive.today/Zx4tG. 
encourage "risk, failure, [and] success." 138 Rather quickly, the eleven state-run companies were transformed into public offerings to foreign companies. This transition was announced in the news media by revealing that the Iraqi government will spend $\$ 1.5$ billion dollars annually for the next two to three years on fifty water and sewage projects, "which will be open to work by foreign contractors."139

Conceivably, this infrastructure reconstruction activity is a sign of recovery. On the other hand, good governance demands the elimination of corruption. In Iraq, corruption has significantly hampered reconstruction efforts. Water sources remain seriously polluted, potable water for ordinary Iraqis remains scarce, and a recent flood caused a dam failure in the south. ${ }^{140}$ A recent trip by one of the authors through Iraq's major cities, including Basra-the economic hub of southern Iraq's oil sector-reveals that many large and luxurious houses are being built, making ample use of the region's deposits of marble and granite. But, just outside these opulent doors, the streets are littered with rubble and remain unpaved and dangerous. Public water services are limited. If the water does run through the city's leaky pipes, it is contaminated-it is neither clean nor potable. ${ }^{141}$ The canals of Basra-a city once heralded as the "Venice of the East"142-are now filled with garbage and raw sewage. The Basra Governorate has seen a population growth of over one million people since 1997.143 Many displaced citizens are crowded into the large slums surrounding Basra. Dislocated Arabs from the Marshlands have erected mud huts under the bridges of the Euphrates where they graze their water buffalo in polluted canals. Violence is commonplace, claiming more than 3,000 lives in the first half

138. Iraq Ministry of Water, supra note 135.

139. John Lee, 50 Water/Sewage Projects Planned, IraQ Bus. NEWS (Sept. 23, 2013), http://www.iraq-businessnews.com/2013/09/23/50-watersewage-projects-planned/.

140. Omar Al-Shaher, Floods Cause Severe Damage in Southern Iraq, AL-MonITOR (May 14, 2013), http://www.al-monitor.com/pulse/originals/2013/05/floods-iraq-raindamages-deaths.html. The dam in Mosul may be one of the most dangerous in the world. It could break down, flooding both Mosul and Baghdad. See Andrew G. Wright, Iraqi Dam Has Experts on Edge Until Inspection Eases Fears, EnGINEERING NEWS-RECORD (May 5, 2003), http://enr.construction.com/news/Front2003/archives/030505.asp.

141. In Basra, a recent study has found that water runs through the public network only $12 \%$ of the hours in the day, while $4.2 \%$ of the population have experienced diarrhoea in the past two weeks. See JOIN'T ANALYSIS \& POL'Y UNIT IRAQ, http://www.japuiraq.org/gp/.

142. Aref Mohammed, Iraq Oil Hub Basra Hoping to See Its Share of Wealth, REUTERS (Aug. 10, 2010, 6:13 AM), http://www.reuters.com/article/2010/08/10/us-iraq-oil-basraidUSTRE6791GX20100810.

143. See Iraq, CITY POPULATION, http://www.citypopulation.de/Iraq.html. 
of 2013 , poised to be greater than in any year since the sectarian violence of $2008 .{ }^{144}$

Iraqis and their communities are impoverished by the violence of war-a corrupt government, a loss of their commons, and lives that are difficult and dangerous. In Iraq, new governance primarily served and continues to serve the interests of the military, private contractors, and Iraqi citizens with high positions in the oil sector, whereas basic security and public services for ordinary Iraqi citizens is overlooked by governance institutions and has harmed them. Freedom subsists not only in the absence of dictatorship or in the ability to cast a vote, but also depends on one's ability to live in safety with dignity, and to have a vibrant, healthy commons to provide for the basic needs of one's community.

For those who would argue that foreign contractors and expertise might be necessary to fix the widespread and serious deficiencies in the Iraqi water governance regime, it is worth considering that Iraq is now considered one of the most corrupt governments in the world according to Transparency International. ${ }^{145}$ This recognized situation of corruption surely shapes the government's negotiations with foreign contractors. The SIGIR Report recommends that governance failures seen in Iraq's reconstruction can be avoided by "planning comprehensively and in an integrated fashion," more "responsive team building," and better "information management systems." 146 Given these significant failures, one must question the precepts of the governance model. Can the new governance mentality of flexibility, adaptation, and private-public partnership bring Iraq's public water infrastructure back even to where it was in the 1970s?

New governance processes may not, in the absence of a moral foundation, be sufficient to fix the mistakes that plagued the Iraq reconstruction efforts. John Braithwaite, a preeminent regulatory scholar, argues that "[a]ll regulatory ideas are dangerous if they are not embedded in a moral philosophy explicitly designed to restrain their excess." 147 Governance scholars must consider whether the extensive decentralization, privatization, and deregulation used to govern the Iraq reconstruction is simply fed back into government and private

\footnotetext{
144. Documented Civilian Deaths from Violence, IRAQ BODY CounT, http://www.iraqbodycount.org/database/.

145. Corruption Perceptions Index 2012, Transparency INT'L, http://www.transparency.org/cpi2012/results (last visited Apr. 5, 2014) (ranking Iraq as 169th and Afyinanistan as tied for last out of 176 countries).

146. SIGIR Report, supra note 89, at xii.

147. Relational Republican Regulation, supra note 114, at 128.
} 
institutions, revealing a dark side of the military's new governance mentality and reinforcing its lack of an environmental ethic.

\section{CONCLUSION}

In this article, we examined a dark side of the new governance theory by considering the U.S. military's new governance mentality (i.e., an adaptive, devolved decision-making organizational model) that mirrors the features of the new governance framework and is reflected in the military's practices, management development literature, and doctrine. By considering the Iraq theatre of war, a danger we uncover is the lack of an environmental ethic of care that is exposed when the features of the new governance model are mapped onto the U.S. military's recent shift to an adaptive mode of governance. We contend that the military's new governance mentality and apathetic attitude toward environmental protection are contributory factors to the devastated state of the environment in Iraq and the country's lack of potable drinking water. An environmental ethic should permeate military doctrine and be directed at the ordinary soldier, whereby his and her actions can remain ordered by "core values of our [globalized] society-respect for quality of life, the environment and human dignity." 148 We further maintain that modern military organizations engaged in large-scale reconstruction efforts should be moral institutions, instilled with an ethic of environmental care, and an administrative structure sufficient to prevent widespread corruption; otherwise, the perils of governance, as predicted by Braithwaite, are unleashed.

Looking at the 2003-2013 Coalition campaign in Iraq through the lens of new governance may lend an interesting perspective on the way new governance has developed within the military and reconstructiondevelopment sectors. We question the precepts of the new governance model in a situation where governance institutions are already weakened, and corruption prevails and perverts the governance regime. With the wide range of actors involved in the Coalition campaign, the differing goals and interests involved, and its overwhelming complexity, it may be difficult to speak of a unified new governance approach. New governance is rather a collection of principles, mentalities, and methods whose outcomes depend greatly on the social and political context, the state of existing governance institutions, and the values and goals that motivate practitioners. A dark side of new governance is exposed when it is placed in the service of goals and institutions that have already

148. Ethical Manufacturing, supra note 69 , at 464 . 
chosen to work through "the dark side."149 This dark side orientation should be offset by the development of core values that uphold a social responsibility, rather than simply methods and processes of new governance.

The complexity, inefficiency, and corruption that characterized the Iraq reconstruction efforts casts a long dark shadow over the new governance model and raises further doubt that this mode of governance is appropriate in post-conflict situations. The myriad of private companies and organizations involved in the reconstruction effort further exposes the precarious nature of this governance model and demands that we think more deeply about whether new governance is itself a mode of governance, or whether these processes are simply laid on top of established governing institutions in order to mitigate entrenched institutional ill effects. If so, then governments and governance scholars should be wary of the danger of imposing these processes onto governing institutions that are already fragile, undeveloped, and inadequate. Instead, the first step should be to lay down a simpler governance framework, in which a small number of private companies and NGOs can play a subordinate and supporting role, so that goal setting and planning can be engaged and adequate methods of accountability can be established by a centralized governance regime-perhaps, at a global, networked scale.

149. U.S. Vice President Dick Cheney stated to Tim Russert in an interview that the administration had chosen to work through "the dark side." Tim Russert, Meet the Press (NBC television broadcast Sept. 16, 2001). 